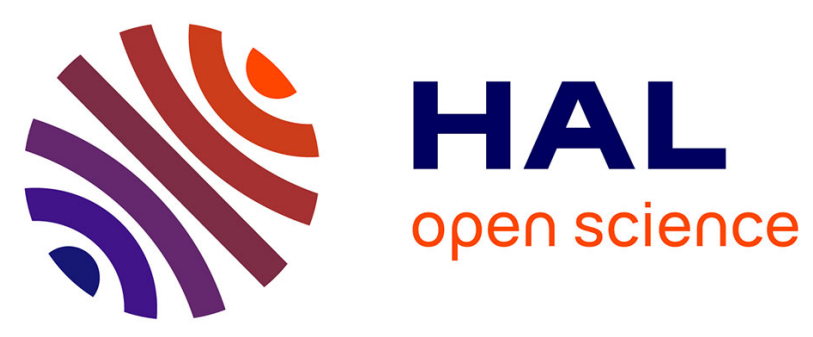

\title{
Governing the future: science, policy and public participation in the construction of the long term in the Netherlands and Sweden
}

\author{
Jenny Andersson, Anne Greet Kaizer
}

\section{- To cite this version:}

Jenny Andersson, Anne Greet Kaizer. Governing the future: science, policy and public participation in the construction of the long term in the Netherlands and Sweden. History and Technology, 2014, 30 (1-2), pp.104 - 122. 10.1080/07341512.2014.932563 . hal-02180036

HAL Id: hal-02180036

https://hal-sciencespo.archives-ouvertes.fr/hal-02180036

Submitted on 11 Jul 2019

HAL is a multi-disciplinary open access archive for the deposit and dissemination of scientific research documents, whether they are published or not. The documents may come from teaching and research institutions in France or abroad, or from public or private research centers.
L'archive ouverte pluridisciplinaire HAL, est destinée au dépôt et à la diffusion de documents scientifiques de niveau recherche, publiés ou non, émanant des établissements d'enseignement et de recherche français ou étrangers, des laboratoires publics ou privés. 


\title{
Governing the future: science, policy and public participation in the construction of the long term in the Netherlands and Sweden
}

\author{
Jenny Andersson and Anne-Greet Keizer*
}

\begin{abstract}
This paper is a historical study of two institutions devoted to the problem of the future - the Dutch WRR (the Scientific Council for Government) and the Swedish Secretariat for Futures Studies - both created in 1972. While there is a growing interest in the social sciences for prediction, future imaginaries and the governance of risk, few studies have examined historically the integration of the category of the 'future' or the 'long term' in political systems in the postwar years, a period in which this category took on specific meaning and importance. We suggest that governing the long-term posed fundamental problems to particular societal models of expertise, decisionmaking and public participation. We argue that the scientific and political claim to govern the future was fundamentally contested, and that social struggle around the role and content of predictive expertise determined how the long term was incorporated into different systems of knowledge production and policy-making.
\end{abstract}

Keywords: forecasting, futures studies, prediction, planning, Sweden, the Netherlands

\section{Introduction: the democratic problem of the long term}

The social sciences are increasingly debating how problems of future temporality and the uncertainties attached to long-term developments enter into systems of governance. In recent years, this debate has been highly influenced by the risk society thesis put forward by Ulrich Beck some 20 years ago and by a large literature on the shifting boundaries between state action, processes of knowledge production and public involvement. ${ }^{1}$ Implicit in this literature is an argument about the long term. This has been especially evident in analyzing complex environmental or technological systems - the signature examples of risk society in which their behavior or performance through time may have significant, even catastrophic, consequences. As such problems rose in importance in the postwar period, they brought forward new relations among governance, time and perceptions of risk. Not surprisingly, resulting prescriptions and policies were contested, often on the grounds of the fundamental uncertainties associated with coming developments. ${ }^{2}$ By 'future' we mean in this paper an object of governance and a category of scientific and political intervention, conceptualized as the 'future' or the 'long term'. This future object was actively construed, we propose, by a shift in planning structures in the 1960s and 1970 s, which drew on the incorporation of predictive technologies such as forecasting or the scenario method. ${ }^{3}$

This paper contributes to this literature and contributes to the historicization of predictive technologies. We study how the long term, or 'future', emerged as a governmental consideration in the postwar period, and how attempts to govern the future as a particular

\footnotetext{
* Jenny Andersson is CNRS senior research fellow at the Centre d'études européennes, Sciences Po, Paris, France. Email: Jenny.Andersson@sciencespo.fr. Anne-Greet Keizer is research fellow, at the Scientific Council for Government Policy, The Hague, Netherlands. Email: keizer@wrr.nl
} 
field of science and politics took shape in European administrations in the 1960s and 1970s. Based on a comparative case study of Sweden and the Netherlands, we propose that the long-term presented fundamental problems of governability for contemporary societies. This was not just due to problems of legitimacy surrounding decision-making structures that extend into the distant or not-so-distant future, but also due to problems of knowledge production and expertise with bearing on social futures. The history of these institutions is therefore illuminating on the way that the long term has been an actual political issue since the 1960s and of the specific problems that, as a particular category of science and politics, it gave rise to. Futures are a quintessentially normative issue, and prediction, as testified by the controversies around the Club of Rome report in 1972 as well as by more recent controversies around climate change, is a contested field of expertise. Our article shows that this contestation has accompanied the rise of forms of future governance, and that studying it is an important contribution to understanding the societal processes in which futures have been actively constructed.

As has been shown by a number of important studies in the last years, various forms of prediction emerged in the $1950 \mathrm{~s}$ and $1960 \mathrm{~s}$ as responses to problems of uncertainty, foreseeability and complexity. This is the case, for instance, of the Delphi and scenario techniques, which both resulted from attempts to model and simulate decision-making in military contexts after World War II. Along with economic, technological and social forecasting, such methods aimed to create visibility to long-term developments and address a future, often conceptualized as a problem of identifying and extrapolating trends. ${ }^{4}$ So far, the literature has emphasized these particular forms of predictive expertise as part of distinct, mainly American, Cold War constellation between militaristic concerns of systems control and social science. The scenario tool, early warning systems and similar predictive technologies have therefore been understood as governmental technologies, given relevance mainly in the context of prevailing notions of risk, disaster and catastrophe. ${ }^{5}$ Indeed, as is most clear in the work by the anthropologist Andrew Lakoff, postwar notions of uncertain futures have appeared as marking a fundamental shift from earlier, welfarist notions of the future as a question of security, calculable risk and foreseeability, to fundamental unforeseeability and 'regimes of constant preparedness'. 6 In other words, prediction has prevailingly been understood as a field in which notions of threat and insecurity gave legitimacy to new forms of expert knowledge and governmental intervention. $^{7}$

While the history of prediction is undoubtedly a history of attempts at control, our paper shows that prediction, in contrast with the existing literature, has been a contingent, often culturally inflected, activity. A variety of actors with very different perceptions were drawn to the possibilities of the future as a form of politics. In particular, we show that technologies such as the scenario method were contested and could be put to use in significantly different ways depending on different national understandings of futures as having more or less open or closed horizons of change. ${ }^{8}$ Indeed, the circulation and reception of predictive technologies forged in a US Cold War nexus in which 'futurology' was, from the $1950 \mathrm{~s}$ on, a key concern, has hardly been studied at all. ${ }^{9}$ As this article shows, while predictive technologies such as forecasting and scenario crafting traveled smoothly from their military origins at the RAND Corporation into the American civilian apparatus, their transfer to Europe was much less smooth. In fact, it was marked by heated debate on the dangers of prediction, and outright rejections of American futurology. Taking these controversies into account changes our understanding of the genealogy of prediction, and uncovers what were arguably central debates of not only the uses but the limits of expertise in a democratic society. 
Shifting the focus from the Cold War nexus to welfare statist European administrations also allows us to trouble the dichotomy between understandings of security and foreseeability as the basis of futures research, and present conceptions of unpredictability and uncertainty, which underpin risk studies. The institutions studied in this article preceded the articulation of risk society concerns of unpredictable systems of threat, whether seen through the lens of biopolitics or potential environmental disaster. On the contrary, they were institutions that began as welfare statist reflections on progress and growth, understood as the fundamental parameters of 1960s and 1970s society. They were primarily concerned with safeguarding welfare state structures in a world perceived as moving toward increased complexity and uncertainty as regarding the future - problems joined together in the label 'long term'.

Though these European actors saw threats to security emanating both from a nuclear world order and from new technological and environmental risks, the fundamental rationale of these institutions was, rather, to oversee shifting social structures, widen prevailing notions of growth and find ways of reaffirming national images of the future. To highlight this European-grounded view, we base our argument on a study of two institutions specifically devoted to the problem of the future, the Dutch Scientific Council for Government Policy (WRR) and the Swedish Institute for Futures Studies (IFS), both created in 1972. In the 1970s, these institutions both drew on new forms of predictive expertise through which they sought to conjoin politics and methods of science to address the problem of the long term. As such, they stood as novel structures and institutional innovations in 1970s planning landscapes. Created as curious intermediaries between bodies of planning and policy advice, Dutch and Swedish government charged their respective institutions with responsibility for overseeing the development of society, forging overarching national priorities and with the production of images and scenarios for the national future. These institutions emblematized the shift in Western planning systems in the period after the late $1960 \mathrm{~s}$, in which such responsibility found ready connection with a tool kit of future-oriented methods: 'futurology', 'futures studies' and other forms of forecasting and prediction. Importantly however, both institutions came about as a result of heated national debates on the future and how it should be governed. In both Sweden and the Netherlands, attempts to incorporate the long term into planning posed problems, pertaining to different understandings of the balance between scientific expertise, policymaking and public participation in the 'social imaginary' of the future. ${ }^{10}$

We structure our argument around three research problems. First, we seek to understand why governmental systems in a number of countries from East to West developed institutions explicitly devoted to the long term in the period from the mid-1960s onwards. This argument requires inserting our cases in a much larger, global debate around the complex field of futurology, forecasting, technology assessment and futures studies in this period. Second, we show that the forms of expertise emanating from this transnational field were received very differently in our two cases, and in both the cases, attempting to govern the future encountered fundamental problems of legitimacy. Central to our analysis here is the suggestion that governing the long term posed particular challenges to established societal models of expertise, decision-making and participation. Third, we show that depending on national interpretations of the democratic role of future expertise, in our two cases, very different approaches were taken to the problem of how to actually perform prediction and use predictive technologies such as the scenario method. In one case, prediction was understood as a highly technocratic activity of foretelling the future, but in the other, it was conceived of as a much more open and reflexive process aiming at providing alternative national scenarios. 


\section{The global field of prediction}

The history of both the WRR and the IFS needs to be contextualized as part of a transnational, especially transatlantic, field concerned with forecasting and prediction that emerged in the 1960s. ${ }^{11}$ While prediction and forms of forecasting have, of course, a much longer history, the immediate postwar period saw important shifts in notions of the future, as the long term emerged as a category of policy intervention. As Andersson (2012) has argued, through the rise of futurology, futures studies and forecasting, the future emerged as a quasi-object, something that could be actively controlled and engineered. ${ }^{12}$ While there were certainly European precursors to forecasting in the interwar period and circulation between European forms of futurism and American futurology, the period after 1945 saw an active transfer of long-range planning methods from the US to Europe. Futurology and futures research was, already through the 1950s, a field of important transnational activity, underpinned by key actors such as the Ford Foundation and part of an American ambition to influence European systems of planning. ${ }^{13}$ Forecasting was discussed as a promising way of addressing the 'problems of growth' in modern societies in the early seminars of the anticommunist Congress for Cultural Freedom, and was the subject for the constitution of important networks of liberal social scientists and planners on both sides of the Atlantic Ocean. From the mid 1960s, the Organization of Economic Cooperation and Development (OECD) actively diffused forecasting tools to European governments as part of new forms of planning for dealing with 'problems of modern societies'. 14

Several of the methods and technologies of 'futurology', in particular the scenario method and also the Delphi tool and other forms of technological and social forecasting, were invented at the American RAND Corporation. In 1964, two RAND researchers, Olaf Helmer and Theodore Gordon, published the paper A Long Range Forecasting Study, which was immediately translated into several European languages. In the paper, they proposed that the 'long range', so far mainly understood as a military concern, could be forecasted and projected for the purpose of planning broader social, technological and cultural aspects of contemporary life. The RAND study was not isolated from European influences. RAND futurologists were in direct contact with European forecasters and modelers such as the French philosopher and political economist Bertrand de Jouvenel, the Dutch economist Jan Tinbergen, and the OECD consultant (and astrophysicist) Eric Jantsch.

As noted, the OECD took an active participation in the problem of forecasting the uncertainties of modern societies, especially through its Committee for Science Policy, created by Alexander King. The committee developed into a transatlantic meeting point for those interested in forecasting as a research problem, including RAND's systems analyst Hazan Ozbekhan, the British sociologist Andrew Shonfield and the Dutch sociologist Evert Willem Hofstee. In 1966, the Committee published a report stating that planning processes were becoming increasingly complex and increasingly difficult to apply to society. This led them to conclude that there was a need for and a lack of long-term thinking supporting the policy process. ${ }^{15}$

The year after, Eric Jantsch published the report Technological Forecasting, in direct dialog with the RAND report. ${ }^{16}$ Jantsch argued for an extended notion of planning that took into account longer time horizons and feedback effects in complex socio-technological systems - in short, taking up the RAND report's call for forecasting research that moved beyond Cold War military problem-setting. As part of the analysis, he also addressed possible environmental consequences and problems of value change and social reactions to 
technologies. These problems, problems of 'advanced' or 'complex' societies, were emphasized again in an OECD seminar on long-range planning in 1968, leading to the so called Bellagio Declaration. The Declaration was the immediate precursor to the creation of the Club of Rome in the following year. It emphasized the new and fundamental interdependence of economic, technological and social change, and the need for new 'apolitical' management tools that could address these outside of the arena of political dispute. ${ }^{17}$ In 1972 , the OECD created the Interfutur program, the purpose of which was to spread the tools of long-range forecasting to national planning systems and to bring together forecasters, systems theorists and planners of different understandings.

As a result of these OECD initiatives, governments in many West European countries started to develop forms of long-range or long-term planning in the period from the mid1960 s onwards. Planning the 'long range' or 'long term' was generally understood to necessitate a more active contribution from the social sciences, mobilized as forms of expertise for the policy process. The tools of modeling, program budgeting and forecasting helped build this expertise, which gained relevance with policy-makers within the framing of 'complexity'. 'Problems of advanced societies' demanded foreseeability and improved tools of anticipation. While forecasting had a long history in economics, the idea of the need to extend horizons of planning to the 'long term', encompassing a series of interdependent variables of change, meant that forecasting methods were extended to a range of fields other than economics. These included those related to technological change, the environment, and to social change and social values, all of which practitioners sought to quantify. Indeed, the OECD put significant effort in the development of social indicators that would allow for the prediction of key social trends including social reactions to economic and technological change. ${ }^{18}$

In some countries, these extended forms of planning were integrated, from the mid1960s on, into preexisting molds. This was the case in France, for instance, where actors such as de Jouvenel, Bernard Cazes, Jacques Delors and Pierre Masse brought forecasting into the heartland of the French state, the Plan. ${ }^{19}$ In other countries, forecasting gave rise to debates on the need for new structures that could incorporate the long term into decision-making. In the UK, forecasting was a key concern of the newly launched Social Science Research Council, chaired first by Michael Young and then by Andrew Shonfield, both convinced of the benefits of forecasting the future. Young chaired the British Commission for the Next Thirty Years, a copy of the American Commission for the Year 2000 chaired by Daniel Bell in the late 1960s. ${ }^{20}$ In Eastern Europe, reform minded social scientists introduced the new forecasting tools to bring attention to the possibility of alternative futures within the communist system (see the Polish Commission for the Year 2000 and the Czech Richta commission), but forecasting was also a tool of control of communist regimes. ${ }^{21}$

Some of the bodies created took the shape of policy advice, for instance the Central Policy Review Staff created by the Conservative Prime Minister Heath in the UK, some, such as the Groupe 1985 led by Pierre Masse and Jacques Delors in France, were part of planning bodies. Some were explicitly technocratic, drawing on, as in West Germany, statistical forecasting and conjectural economic planning, while others were qualitative investigations of fundamental patterns of change, for instance, in the Dutch case, charged with pondering 'priorities for the long term'. ${ }^{22}$

Forms of future planning were thus developed with a wide range of initiatives on the national and transnational level, and carried by networks of actors that bridged the divide between the social sciences and planning. But the national reception of forecasting technologies differed substantially, depending, arguably, on heritages in political culture and 
planning structures but also on the shape of key national debates on the uses of predictive expertise. In most of the cases cited above, forecasting was understood as a potent technology of social control. For instance, in France, social indicators were developed by the Plan after 1968, with the idea that future value revolutions must be foreseen, at the possible cost of mobilizing the totality of French social science within the planning apparatus. ${ }^{23}$ What makes our cases stand out in this larger transnational history of forecasting is that in both Sweden and the Netherlands, national debates regarded forecasting as forms of expertise that because of their potential power in the political process should be put under democratic control. The creation of institutions and structures for the long term reflected these debates.

In order to explain this, we need to outline the national contexts of our two cases. In both of these countries, political culture was deeply committed to the idea of progress and welfare in the postwar period. But in both countries, there was also by the mid-1960s, the idea that existing modes of problem solving had reached their limits. In both countries, debates erupted concerning the question of which social actors should be involved in the planning process, and how scientific expertise and public interest should be balanced. The problem of the long term entered into these debates. In both the Netherlands and Sweden, planning systems were dominated by corporatist forms of representation that had developed since the interwar period, grounded in existing national alliances and models of policy-making. In Sweden, this was marked by the prevalence of the idea of a particular Swedish model of welfare state, in the Netherlands by the physical rebuilding after the World War II. ${ }^{24}$ In both countries, planning was also highly technocratic, dominated in Sweden by the economic five-year plan, the langtidsutredning, and in the Netherlands by the Central Plan Buro created in 1945 by the econometrician Jan Tinbergen. ${ }^{25}$ By the late 1960 s, this setup came under criticism, rivaled in both countries by ideas of the need to develop new forms of cross-sectoral planning and to re-think indicators of growth to include measures of environmental degradation and quality of life. This debate against planning as a technocratic, narrow activity was inspired by the emergence of alternative forms of knowledge in the shape of systems analysis and futures studies, emanating from the universities and from the rise of the New Left. In both Sweden and the Netherlands, these debates found an initial echo in ruling social democratic coalitions, concerned with the critique of 'one dimensional society'. ${ }^{26}$

\section{Whose future? Science, policy and public participation in the creation of WRR and IFS}

Forecasting was part of a range of approaches that aimed, specifically, to improve the foreseeability of future events in order to be able to act on them and prevent or mitigate undesirable forms of change. As a technology of control, forecasting promised to extend the reach of national planning into the future. But from the late 1960s on, forms of forecasting, modeling and systems analysis found use, too, not just by state entities but by actors from the global peace and environmental movement as a means of critique. Future studies, associated with intellectuals such as the Dutch systems analyst Fred Polak, the West German journalist Robert Jungk or the Norwegian international relations theorist Johan Galtung, rejected prediction and 'American futurology' such as the scenarios performed by the nuclear strategist Herman Kahn. Futures, they argued, should not be predicted but actively shaped, but not by means of futurological expertise or predictive technologies, but by means of the human imagination and by forms of public participation. ${ }^{27}$ From the late 1960 s, spurred on by the controversy around the overshoot 
and collapse scenario of the Club of Rome report, the field of forecasting and futures research was therefore torn between fundamentally different ideas of how, why and by whom, the future should be studied and planned. ${ }^{28}$

The differences between our two cases can be explained in terms of how they relate to this dividing line in interpreting the political use of prediction. The driving force behind the WRR, Willem Hofstee, chairman of the Social Research Council of the Dutch Royal Academy for Science, was a member of the OECD Science Policy Committee, and a direct transmitter of the OECDs prevailing approach to forecasting as a technocratic activity of planning and expertise. For an OECD conference in 1966, Hofstee wrote a memorandum arguing that other countries should also set up dialogues between social scientists and policy-makers to deal with issues of long-term developments and futures. ${ }^{29}$ In Sweden, the key actors behind the creation of the Secretariat for Futures Studies were Alva Myrdal, Nobel Laureate in 1982 for her work in disarmament, and the professor of physics and systems analysis Lars Ingelstam. They had both been following closely the international debate which posited 'critical futures studies' against 'establishment futurology' and they were closely connected to the international peace and environmental movements. These different actor positions explain the way that predictive technologies were received and translated into institutional structures.

The eventual construction of the Dutch Council, the Scientific Council for Government Policy, reflected explicitly technocratic ideas about how to strengthen the planning system and make use of the social science in the policy process. In fact, Hofstee orchestrated a direct dialog between a group of high civil servants and the Social Research Council. This dialog took place with the intention to create a direct relationship between social science and policy, as part of an attempt to modernize the social institutions of Dutch society after a focus on economic reconstruction in the decades immediately after the war. ${ }^{30}$ In 1970 , this dialog resulted in a first proposal for a 'meta' planning council, a kind of trans-sectorial supra agency for policy advice that would be placed, its proponents suggested, within the Dutch government. It called for membership on the basis of scientific excellence, with an aim 'to provide insight into the long-term development of society as a whole and in certain policy areas, as part of scientific analysis for long-term government policy as a whole'. ${ }^{31}$

A special committee appointed by the government and led by another professor, the statistician Peter De Wolff, prepared the proposal for this super-body of planning. The committee consisted further of a number of high civil servants working for planning departments and bodies such as the CPB and Statistics Netherlands (CBS). One of the more critical members was the director of the National Spatial Planning Agency, Theo Quené, who would later become the second chairman of the WRR. Quené was critical of the grandness and technocratic nature of the proposal in the final report, but held back, out of 'respect' for the senior professor Hofstee. ${ }^{32}$ Actors with a scientific interest in modeling and forecasting dominated the committee, which worked, for the most part, behind closed doors. This closed structure led to protests as the proposal was presented to the Dutch government in 1971. These protests came from Dutch social movements, led by the Working Group 2000, which drew members from Dutch churches, including the Roman Catholic Church in Amersfoort and the Dutch Reformed Institute in Driebergen, and from the Dutch New Left, including individuals such as the systems theorist and political science professor Bart van Steenbergen. They replaced the traditional catholic idea 'the future is in the hand of God' by 'the future is in our hand'. ${ }^{33}$ The Working Group 2000 was a faith based and humanistic organization, which aimed to explore the future and work for the improvement of the 'future consciousness' of the Dutch public. ${ }^{34}$ 
Some of the members of the Working Group 2000 participated actively in the international futures studies field, notably Bart van Steenbergen, who worked with some of the more radical futurists, for instance Johan Galtung and Robert Jungk, and himself had been outspoken on the use of methods of forecasting in the hands of elite military planners. The Working Group 2000 dismissed the proposal for a super planning council as a 'pact' between policy-makers and scientific experts over the future. Futurology, they insisted, should not be an instrument of the 'establishment'. 35

In Sweden, the first proposal for an institute for 'futures studies' also came from a distinctly technocratic background in the Academy of Engineering Sciences, IVA, in 1967. ${ }^{36}$ IVA had been instrumental in introducing Taylorism and scientific management to Swedish industry in the interwar period. In the postwar period, IVA played again a similar role by importing operations research and systems analysis to Sweden. ${ }^{37}$ The 1967 proposal introduced the idea of a government institute for technological forecasting and technology assessment. ${ }^{38}$ This met with a storm of protest, led by actors in the Swedish Left with direct connections to the international field of systems analysis and ecology - particularly Ingelstam and the environmentalist Arne Engström, who had followed closely the activities of the Club of Rome and was highly critical of its world models. ${ }^{39}$ In the 1970s, Engström became the architect behind the Swedish Environmental Agency. Both Ingelstam and Engström were socialists, interested in the idea of futures studies as an active means to shape the world; crucially, they had a direct relationship to ruling Social Democratic Party. 'Futures studies' emerged as a key area of discussion in Sweden in the new Board of Research, created in 1964 under the direct leadership of the Prime Minister (Tage Erlander). The Social Democratic Party saw such research as part of a broader strategy to develop a proactive science policy that included mobilization of the social sciences. ${ }^{40}$ By 1968 , however, the relationship between the Party and social science had become strained. The universities were the bastion for a New Left opposition, and Swedish social scientists such as Gunnar Myrdal, husband of Alva, began a debate on planning as a necessarily normative and value based activity. ${ }^{41}$ In this context, the Party started to see futures studies as a possible way of entering into dialog with its critics on the Left, and connecting social science research to a broader view of national strategic policies and goals. In 1969, new Prime Minister Olof Palme oversaw the appointment of a specific Working Group for Futures Studies within the Board of Research, under the chairmanship of Alva Myrdal and which included Lars Ingelstam as a member. Its other members were senior representatives of the humanities and the social sciences, including an historian, a psychologist, a geographer and an economist.

From the very beginning, the Working Group adopted a particular perspective on the possible use of predictive expertise, firmly rejecting expert rule and the idea of 'future dictators'. ${ }^{42}$ The problem of legitimacy surrounding the long term, they argued, should be solved not by another planning body, nor by the creation of a committee of experts, but by developing new dialogs between social science and citizens around future visions. The idea of neutral science was rejected, instead stressing the idea that science and particularly futures oriented research had fundamental public responsibilities. Genuine participation, the group concluded, hinged on the creation of a particular form of 'public long term consciousness', for which futures studies were instrumental. Futures studies were understood as a kind of action science, designed to foster 'genuine decision-making' and 'genuine participation'. 43

The above shows the different interpretations that became embedded in possible forms and uses of futures studies. In contrast to the Swedish case, in which futures studies were thought of as a way of creating a public dialogue about future developments, the Dutch 
debate rapidly marginalized social actors like the Working Group 2000 and the idea of participation and dialog. The relationship between expert rule and democratic representation was not ignored, but had a lesser priority than the problem of providing structures for relevant scientific expertise. The De Wolff committee explicitly addressed the fear of technocracy, and stated that planning should be viewed as 'a joint effort to promote the development of society, in a way acceptable for Dutch society as a whole'. ${ }^{44}$ The initial proposal for a Planning Council included suggestions for a structure in which members consulted with important interest groups in Dutch society. But the Dutch government, responding to public concern with technocracy, decided the proposal for a super planning body too far-reaching. ${ }^{45}$

However, the idea of a new institute for 'long term priorities' resurfaced in preparations for a new cabinet after the 1971 election. A new committee, again with predominantly professors and high civil servants as members, concluded that an institutional mechanism was needed which could convey the insights of the social sciences on longterm developments to policy-makers, hence making future social developments visible. ${ }^{46}$ Such an institutional mechanism was no longer thought of as a planning body, but as a scientific council for government policy, the task of which would be to develop scientific future visions of society in support of long-term policy-making. ${ }^{47}$ The proposal for the Council included a measure of public deliberation by making the Council responsible for gathering information from society, as well as from science, fitting with the Dutch tradition of expert representation of public interests. In this manner, the issue of participation was directly connected to, but also made subordinate to, expertise.

\section{Democratic safeguards to prediction: creating institutional structures for the future}

In the Netherlands as well as in Sweden, the debate surrounding the initial proposals for new governmental structures to deal with the long term revealed fears of predictive science as a particular form of power over the social possibilities of the future. As a consequence, it inspired counter mobilization and protest. Such resistance was part of a broader movement in Europe as well as in the United States in which 'futurology' stood as synonymous with policies of preparing a nuclear apocalypse and extending Cold War forms of geopolitcal dominance into the future. Indeed, Herman Kahn's works Megadeaths and On ThermoNuclear War, in which he introduced the scenario method to a public audience, were read in Europe, and interpreted by the peace movement as utmost folly. ${ }^{48}$ The Club of Rome report Limits to Growth in 1972 was, as discussed, highly contested and attacked for its neo-Malthusian approach to world population and for scenarios that projected doom and disregarded the possibility of large-scale value change. ${ }^{49}$ This contestation around the meaning and uses of prediction impacted differently the actual writing of national scenarios for Sweden and the Netherlands. In both countries, the strength of social reactions to the initial proposals for the Council and the Secretariat led to reflections on how to create institutional structures that provided avenues for participation and established democratic safeguards. It is interesting, however, that different solutions were found to this problem; in the Netherlands, the debate focused on where to situate the Council in relation to government and parliament; and in Sweden, the debate focused on epistemological principles for futures studies.

The construction of the Dutch Council reflected a search for an institutional balance of interests. Although the Council was installed in November 1972, it was not until 1976 that the act of establishment passed parliament, limiting the manner in which it was able to influence an effort well underway. Meanwhile, in the process of passing the act, social 
actors were invited to respond to the draft bill, which allowed some religious and social organizations, including the Working Group 2000, to comment. The Groen van Prinsterer Stichting, the scientific bureau of the Dutch Reformed Political Party (GPV), replied that gaining insight into future society was not only a matter of science, but of religion and philosophy as well. ${ }^{50}$

In addition, the Working Group 2000 critiqued that the Council would strength government power at the expense of parliament. They proposed changing the design from a council for government into a council for parliament, which would facilitate democratic debate over the future of Dutch society. This particular issue of the parliamentary control of futures research resurfaced in debate over the act of establishment. In a meeting with the parliamentary committee, members of the WRR agreed that there existed the risk of creating an elitist institution. ${ }^{51}$ As a result, the parliament and the WRR agreed to communicate and the government gave parliament the right to initiate meetings with its members. ${ }^{52}$

The work of the Council was also clearly demarcated from political life. In his speech at the official installation of the Council, in November 1972, Prime Minister Biesheuvel emphasized the need to make future-relevant knowledge available to the policy process, but he also stipulated that the WRR was not to interfere with the affairs of public administration or political decision-making. ${ }^{53}$ The final phrasing of the act of establishment of the WRR defined its tasks as to supply government policy with scientifically sound information on developments which may affect society in the long term, to provide a scientific structure which government can use when establishing priorities for policy, and improve policy co-ordination. ${ }^{54}$

In the formulation of these tasks compromises on issues that dominated the preceding debate were now built into the institution. Fear of technocracy inspired the formulation that the Council was to offer 'information' and not 'advice'. The position of parliament was strengthened by the stipulation that information should be supplied for government policy and not to the government directly, as parliament was given the right both to approve policy propositions from the WRR and the right of initiative. The act of establishment also strengthened democratic accountability by requiring government to respond to reports of the Council within a fixed term of three months. This stressed the public nature of the expertise produced by the Council. At the same time, the act included safeguards for scientific independence. It specified that Council Members held their appointments for a five-year term, extending beyond the four-year cycle of government elections. As qualification, Council members had to possess distinguished academic credentials, sometimes combined with experience in politics or administration. The Council was to determine its own program, although it should consult, in this process, with relevant stakeholders, including cabinet members. Yet, in this careful balancing of political and technocratic interests in futures studies, the issue of public participation and representation of wider social interests did not become a strong element in the institutional design. The issue of participation and legitimacy would therefore become a recurring topic of discussion surrounding the activities of the Council, sometimes accused publically for its technocratic nature. ${ }^{55}$

This process of negotiating interests and safeguards in the institutional construction of the WRR had, however, no equivalent in Sweden. The Working Group presented its report to Prime Minister Olof Palme in 1972, with the suggestion to create a specific Secretariat for Futures Studies within the Prime Minister's Council. The report of the Working Group was pre-circulated to a wide range of social actors ranging from trade unions to research institutions and civil society. A number of public seminars and 
hearings were organized, and a civil society association for futures studies created in order to provide public input on the Secretariat's activities. Part of the report even gained popularity in the form of a cartoon.

On 1 February 1973, the Secretariat began its work as part of the Council of Ministers. Its primary directive was to 'promote public debate around future developments, on the basis of a social science footing'. ${ }^{56}$ Its loose organization reflected specific motivations. The Working Group had examined the basis for future studies and forecasting in other national contexts. Soviet and American strands of forecasting were dismissed. The Swedes regarded the organization of the French Groupe 85 around a team of planistes such as Pierre Masse and Jacques Delors as too technocratic and elitist. ${ }^{57}$ But the first proposal for a Dutch planning commission drew significant interest, especially the difficulty of integrating fully futures studies into the political process and thus relying on the creation of a council of high level experts. ${ }^{58}$ In Sweden, such a solution was impossible, since the guiding principle was the emphasis on the public control of science and the question of public participation.

The act establishing the Secretariat did not precisely specify its procedures or its activities. In the first years of its existence, the Secretariat began four projects, on working life in the future, the international political environment, the exploitation of natural resources and energy futures. ${ }^{59}$ These four areas resulted from discussion within the Secretariat and with the Prime Minister. In this discussion, input to immediate planning needs was pitted against the production of more visionary alternative futures of Sweden and the world. ${ }^{60}$ The Prime Minister proposed to distance the Secretariat from issues of planning and push it into the direction of a high-level think tank, making it easier to pursue alternative future scenarios but with an unclear relation to policy. ${ }^{61}$ This position resulted from a critique of the Secretariat by other political actors, particularly the Liberal Party (Folkpartiet) for which it was unacceptable that a social democracy within its own government had created an agency for the propagation of socialist futures. The Liberal Party filed several motions in parliament on the need for independent futures research in the name of the public and democratic interests. ${ }^{62}$ The issue was not solved. When, in 1974, the government reorganized research, it created independent disciplinarily organized research councils. This included a committee devoted to long-term research; as a result part of the research coordinating task given to the Secretariat was removed. In 1975, further debate about the organization of futures research, particularly the lack of parliamentary control, led to the addition of a parliamentary representative to the Secretariat. Its work thus became dependent on the parliamentary process and the link to government weakened. In 1979, the newly elected Liberal Conservative government placed the Secretariat under an agency overseeing the research councils, further weakening its policy role, and, in 1985, it was transformed into an independent research institute. ${ }^{63}$

\section{Framing the future: prediction or exploration}

While the institutional setting differed in each case, more important was their difference in the use of forms of prediction and how each body embarked on the activity of crafting scenarios for the national future. As we have seen, the organization of the Dutch Council did not include participation from groups which saw the future not as a problem of planning but as a fundamental problem of democracy. In its work, the Council minimized influences from the field of futures studies, personified in the Dutch case by Bart van Steenbergen. In Sweden, however, the field of futures studies played a central role, as it was constituted around an ethos of non-technocratic and non-military approaches to 
forecasting and prediction. Indeed, in Sweden, the interest in futures studies emerged from the idea that the long term was a key means for maintaining national sovereignty and neutrality, and that forms of future knowledge had to be developed to protect from super power attempts to influence images of the future. American futurology was dismissed as a way of colonizing world futures and meddling with the capacity of neutral countries to think the future. Likewise, the Swedes rejected the world models of the Club of Rome as reenacting fundamental inequalities between the developed and the underdeveloped world. ${ }^{64}$

The Working Group identified futures studies as a particular form of knowledge production with a specific role for democracy. It stood as a form of intermediary expertise between science, planning and policy and even as a form of public good. It defined the role of futures studies so as to ensure that societal developments took place within a framework of democratically controlled objectives, including within planning. The Group coupled the principle of overseeing the health of democracy with a second principle, that of representing the interests of coming generations. Futures studies could be used, they argued, to promote the specific interests of subsequent generations and the politically voiceless by providing the policy process with analysis of the long-term effects of present decisions. $^{65}$

In addition, the Working Group argued that present societal trends already posed direct problems for representational politics. A growing number of decisions, mainly economic and technological, seemed to be made outside of democratic control, especially in the spheres of science and industry. Second, a multitude of decisions occurred in society on a variety of different levels, without any concerted study of the resulting complexity of effects. Third, many questions managed by government tended to be so complex that citizen participation was rendered impossible. ${ }^{66}$ These observations led to a number of conclusions in the form of epistemological principles for the use of futures studies as a form of 'public science'. First, 'futures-creating scientific activity' should aim to deepen the democratic process - by providing information to different social actors and by offering routes of participation for citizens as well as creating a civic 'long term consciousness'. Second, the Working Group regarded images and discourses produced by science as central forms of power over the future. Futures studies therefore had a particular democratic responsibility for including in their analyses representation of future visions held by groups in society lacking influence. Third, in order to enable 'genuine decision-making', futures studies should produce alternative and plural futures, thereby enabling democratic discussion and choice. Thus, futures studies should seek to identify which ongoing processes in society were amenable to political action and those that were not. Importantly, the Working Group emphasized futures studies as a way to challenge other forms of scientific knowledge, especially those presented as deterministic (such as the plausibility of different energy sources). In other words, the promise of futures studies did not lie in prediction, but in exploring possible futures.

This particular approach to predictive expertise was reflected in one of the most important reports of the Secretariat, produced in the aftermath of the oil crisis under the title Solar vs Nuclear: a Participatory Use of the Scenario Method. ${ }^{67}$ In fact, the report turned the scenario method, as used by Kahn and the Club of Rome, on its head. ${ }^{68}$ It did not produce a number of likely scenarios, but a number of possible energy scenarios that raised fundamental questions as to the desirability of the future represented. Outlining different possible technological paths (investment in renewable or nuclear energy) the report described their likely consequences in terms of dependencies, technological lock-ins and long-term effects on Swedish society. The report presented the scenarios as a basis for 
public choice and debate. Solar vs Nuclear prepared the ground for the referendum on nuclear energy that was held in 1981. It sold 25,000 copies and was translated into English. ${ }^{69}$

The WRR, on the other hand, took prediction seriously. The official task of the Council, to provide scientifically sound information as a basis for long-term priorities, was in fact vague. Over time, it became even more so, as the WRR came to the conclusion that prediction was a very difficult activity. One of the first projects the Council started in 1973 was A General Future Study (GFS, AlgemeneToekomstverkenning). The report was inspired by the scenario technique and modeling performed in the Club of Rome report, published the year before. But it also took note of the fundamental contestation surrounding Limits to Growth, not only in the public sphere but also in the form of a series of counter scenarios produced by William Nordhaus and Herman Kahn. ${ }^{70}$ This contestation led to a significantly more docile second Club of Rome report in 1974, and stimulated the Council to dismiss the scenario method as a tool for creating several alternative worlds. ${ }^{71}$ As a consequence, the GFS provided instead a forecast integrating a broad spectrum of political, administrative and social trends. In line with its mission to improve the 'integrality' of government policy, the Council decided to perform a synoptic study, which had as its explicit aim to predict the future of Dutch society. Several experts joined the research team, providing input on the domain of their specialization, but none were from the field of futures studies. The Council envisioned 16 sub-studies of different domains, with the goal of determining probable developments in each field. But the ambition to produce a total future study of Dutch society rapidly stumbled on methodological problems. It proved too difficult to provide an integrated, total vision of the future. The Council therefore downgraded the report from an 'integral' to a 'general' futures study. ${ }^{72}$

Moreover, instead of modeling possible unknowns, the Council decided to use a 'surprise free' approach, in other words a simple extrapolation of current trends and refrain from the production of alternative scenarios. In a memorandum to the Prime Minister, the chairman of the Council acknowledged: 'The reason for this decision is that we are not capable of doing it differently. (...) Is there a point in such a 'timid' future study? That remains to be seen'. ${ }^{73}$ In the end, the report was a study of two alternatives of economic development; an alternative $\mathrm{A}$, assuming a moderate economic growth (about $3 \%$ in a year); and an alternative $\mathrm{B}$, which predicted a gradual reduction to a zero growth rate by the year 2000 .

The GFS was understood as a failure both within and outside the Council. It had not produced a scientifically sound nor convincing image of the future and failed to engage with the public debate surrounding futures studies. ${ }^{74}$ The report did not fulfill the ambition of providing policy recommendations for the long term. Prime Minister Den Uyl criticized it, dismayed that the extrapolation of current developments to the year 2000 ignored all possibilities of social reactions or political change. ${ }^{75}$ These experiences led to the conclusion within the Council that 'futures studies' should be pursued with much less ambition. Instead of integral studies of the total future of Dutch society, The Council directed new projects at trends and scenarios in specific policy areas. In 1980 and 1983, the Council published Policy-Focused Future Studies (PFFS, BeleidsgerichteToekomstverkenning), which analyses received little attention. The WRR therefore soon stopped producing futures studies, losing over time its focus on the long term in favor of a focus on scientifically grounded policy advice. In other words, the methodological failure of science-based prediction eroded its legitimacy as a form of policy related expertise. Not least, the lack of public insight into the production of scenarios also created a recurring 
problem with criticisms of technocracy. Meanwhile, there were several other attempts to create futures studies in the Netherlands, resulting in the establishment of several other Dutch research institutes devoted to long-term developments, for instance, in matters of the economy or climate. The futurist Fred Polak, an important figure in the futures studies field following the publication of the book The Image of the Future in 1956, but who was not included in the Council preparations, created a foundation for the scientific study of the future, which developed over time into technology assessment. Several university chairs, in Leiden, Maastricht and Twente, were also devoted to futures studies. Despite such initiatives futures studies never found a home in the Dutch policy process. ${ }^{76}$ The WRR, nevertheless, would continue to be an active presence in the Dutch public debate. In 2010, it published an overview of future studies, but it would never again experiment with prediction. ${ }^{77}$

\section{Conclusion}

This paper has described the emergence of the category of the long term, or future, as a problem of governance in the 1960s and early 1970s, tracing the translation of forms of predictive expertise into national policy-making structures as part of a response to specific ideas of uncertainty and complexity of the period. While a number of studies have highlighted the role of predictive technologies as tools of control for shaping unforeseeable futures in the postwar period, we have shown that predictive technologies were received, and used, in different ways in different European administrations. Importantly, they were surrounded by debates on the democratic limits of prediction. In other words, the long term was a contested category, and forms of futures expertise and future governance were shaped in processes of social struggle of central importance to the historical actors. This struggle concerned the question of how futures should be represented, by whom, and with what balance among science, policy-making and public participation. As shown by our two cases, the long-term challenged existing systems of knowledge production, planning, decision-making and representation. Attempts to extend horizons of planning towards the 'future' in the 1960s and 1970s thus encountered various forms of protest, leading to the development of alternative forms of future knowledge based on the rejection of prediction. In other words, historical actors understood predictive expertise as having a direct bearing on the forging of social futures, with the potential for far-reaching consequences. This stimulated attempts to find institutional solutions that embedded prediction in democratic processes and to recast its purpose to serve as a resource for public debate and not a privilege of experts. While the WRR experimented, and failed, with science-oriented prediction, the IFS chose to use predictive methods as a way of illuminating possible futures and opening up horizons of change. The failures vs. successes of prediction in our story is therefore directly related to the question of public participation and the democratic anchoring of futures. Ultimately, we propose that our cases illustrate a central aspect of both the history of science and technology, and political history, namely that the long term has been an object of governance that challenges both processes of scientific expertise and systems of governance. The public role of science and expertise seems to become particularly acute in debates of predictive knowledge, in other words when social futures are concerned. In addition, attempts to govern the long term, historically as well as in the present, challenge systems of representation and understandings of democratic control. This problem was and is of central importance for our understanding of the relationship between science and policy in the postwar period. 


\section{Acknowledgment}

We want to acknowledge the helpful assistance by Nina Faas in gathering some of the materials for the Dutch case

\section{Notes}

1. Beck, The Risk Society; Callon, Lascoumes and Barthes, Acting in An Uncertain World.

2. Adam, Timescapes of Modernity; Brown et al. Contested Futures.

3. We use the term predictive technologies since forms of prediction were designed both as methods, with which to arrive at accurate representations of the future, and as technologies with which to actively influence futures.

4. Mallard and Lakoff, "How Claims to Know the Future Are Used to Understand the Present", Ghamari-Tabrizi, The Worlds of Herman Kahn; Andersson, "The Great Future Debate and the Struggle for the World".

5. Mallard and Lakoff, "How Claims to Know the Future Are Used to Understand the Present"; Ghamari-Tabrizi, The Worlds of Herman Kahn.

6. Lakoff, "Preparing for the Next Emergency".

7. Aradau and Munster, The Politics of Catastrophe, chapter 2; Andersson, "Controlling the American Future. RAND, the Commission for the Year 2000 and the Rise of Futurology".

8. Aykut, «Comment gouverner un 'nouveau risque mondial'? La construction du changement climatique comme problème public à l'échelle globale, européenne, en France et en Allemagne».

9. Dahan-Dalmedico, Les modeles du futur, "Models and Simulations in Climate Change. Historical, Anthropological and Political Aspects"; Andersson, "The Great Future Debate and the Struggle for the World".

10. Jasanoff, Designs on Nature; Jasanoff and Kim, 'Sociotechnical Imaginaries and National Energy Policies'.

11. Hounshell, "The Cold War, RAND, and the Generation of Knowledge".

12. Andersson, "The Great Future Debate and the Struggle for the World".

13. Andersson, "Controlling the American Future. RAND, the Commission for the Year 2000 and the Rise of Futurology".

14. Schmelzer, "In the Hallways of the OECD: the Forgotten Origins of the Club of Rome", 2. The OECD was created in 1948 in order to oversee the implementation of the Marshall plan.

15. OECD, The Social Sciences and the Policies of Governments.

16. Jantsch, Technological Forecasting.

17. Schmelzer, "In the Hallways of the OECD: The Forgotten Origins of the Club of Rome", 7.

18. OECD, Science, Growth and Society. A New Perspective.

19. Guiader sociohistoire de la prospective.

20. Young, et al. Forecasting and the Next Thirty Years; Bell and Graubard, The Year 2000, Work in Progress.

21. Sommer, "From Futurology to Prognostika. Czechoslovak Futures Studies from 1968 to 1989".

22. Keizer, "Evenwichtskunstenaars tussen beleid en wetenschap"; Vieille Blanchard, «Les limites a la croissance dans un monde global»; Andersson, "Choosing futures. Alva Myrdal and the Construction of Swedish Futures Studies 1967-1972".

23. Commissariat au Plan, Plan et prospective.

24. Fridjonsdottir, "Social Science and the Swedish Model"; Halfman. "Measuring the Stakes: The Dutch Planning Bureaus.

25. Stenlas et al., Science for Welfare and Warfare. Technology and State Initiative in Cold War Sweden.

26. Marcuse, One Dimensional Man. Marcuse's argument exercised a profound influence on the European New Left. Marcuse saw advanced society and its political regimes as a form of social repression, in which individuals were pacified by affluence, consumerism and rising standards.

27. Andersson, "The Great Future Debate and the Struggle for the World".

28. The Limits to Growth, published in 1972, led to a huge controversy around not only the results presented in the report, an overshoot scenario where world production led to the depletion of 
resources and the pollution of the atmosphere, but also of the use of the scenarios created through the computer 'World model' created by MIT mathematician Jay Forrester.

29. Den Hoed, 'Een keur van raadgevers: honderd jaar vaste adviescolleges'.

30. Den Hoed, 'Een keur van raadgevers: honderd jaar vaste adviescolleges'.

31. Tweede Kamer, Rapport van de Commissievoorbereidingonderzoektoekomstigemaatschappijstructuur, 2-4.

32. Den Hoed en Keizer, Op steenwork afstand.

33. http://www.wergroep2duizend.nl.

34. Van de Linde, "Een korte geschiedenis van de naoorlogse praktijk van toekomstverkenning in Nederland"; interview with Bart van Steenbergen, August 10, 2012.

35. Van Steenbergen, 1970; Van Steenbergen 1971; Kalk 1971.

36. IVA was created in 1919 with the purpose to further Swedish industry and the engineering sciences.

37. Tiberg, "Framtidsstudier - vad hände sen?".

38. IVA, förslag till ett institut for framtidsstudier; Wittrock, Möjligheter och gränser. Framtidsstudier i politik och planering, 35-39.

39. Ingelstam and Nibleus, 'Socialistiska framtidsstudier'.

40. Stenlas et al., Science for Welfare and Warfare. Technology and State Initiative in Cold War Sweden.

41. Myrdal, Planering som värdeproblem.

42. Swedish National Archives, Working Group for Futures Studies, protocol May 18, 1971.

43. Att välja framtid, 10-12.

44. Tweede Kamer Rapport van de Commissievoorbereidingonderzoektoekomstigemaatschappijstructuur, 8.

45. Den Hoed, 'Een keur van raadgevers: honderd jaar vaste adviescolleges'.

46. Dutch National Archives 2.03.02/12029.

47. Dutch National Archives 2.03.02/12030.

48. Nehring Erickson.

49. Vieille Blanchard, «Les limites a la croissance dans un monde global».

50. Dutch National Archives 2.02.28/6968.

51. Dutch National Archives 2.02.28/3.

52. Over the years, the Dutch parliament has not exercised this right very often.

53. Dutch National Archives 2.02.28/6968.

54. Act of June 30, 1976.

55. Den Hoed and Keizer, "The Scientific Council for Government Policy: Between Science, Policy and More".

56. Protocol, Statsrådsberedningen, February 1, 1971, Swedish National Archives, Working Group for Futures Studies.

57. Att välja framtid, 76.

58. Protocol, Forskningsberedningen, January 1st 1972, Swedish National Archives, Working Group for Futures Studies.

59. Secretariat for Futures Studies, 1974, 1975.

60. Secretariat for Futures Studies, memos 19730822, 19730926, 19740,820. Swedish national archives, Working Group for Futures Studies.

61. Wittrock, Möjligheter och gränser. Framtidsstudier i politik och planering, 127.

62. Aner, motion in parliament, 1974.

63. Forskningsrådsnamnden.

64. See letter from Hans Palmstierna to Alva Myrdal, Working Group for Futures Studies (Arbetsgruppen för framtidsstudier), Alva Myrdal's Archives, Labour movements' archives, Stockholm, vol. 5.

65. Att välja framtid, 12.

66. Ingelstam "Socialdemokraterna och framtidsforskningen"; Oden, Planering, värdestruktur och participation, 9, 16, 32.

67. Ingelstam Solar vs Nuclear. Choosing Energy Future.

68. Kahn, On Thermonuclear War, Kahn and Wiener, The Year 2000, Meadows et al., The Limits to Growth.

69. Ingelstam Solar vs Nuclear. Choosing Energy Future. The referendum in 1980 on nuclear energy was a clear mandate for a gradual dismantling of nuclear energy in Sweden, but as 
referendums are only indicative in the Swedish political system, and not binding, this decision has still not been implemented.

70. WRR, De komende vijfentwintigjaar: een toekomstverkenning voor Nederland, Van der Duin et al., Vijfentwintig jaar later. De toekomstverkenning van de WRR uit 1977 als leerproces, 33, van der Linde, Uit Zicht, 164.

71. Mesarovic and Pestel, De mensheid op een kruispunt.

72. Dutch National Archives 2.03.07/7501.

73. Dutch National Archives 2.03.07/7501.

74. Van den Linde, 'Een korte geschiedenis van de naoorlogse praktijk van toekomstverkenning in Nederland'.

75. Dutch National Archives 2.03.07/7501, van der Duin et al., Vijfentwintig jaar later. De toekomstverkenning van de WRR uit 1977 alsleerproces, 11.

76. Polak, 1955; Van de Linde 2010; Van der Helm, 2005.

77. WRR. 2010. Exploring Futures for Policy-making.

\section{References}

Adam, B. Timescapes of Modernity. London: Routledge, 1998.

Andersson, J. "Choosing Futures: Alva Myrdal and the Construction of Swedish Futures Studies, 1967-1972." International Review of Social History 51 (2006): 277-295.

Andersson, J. "The Great Future Debate and the Struggle for the World." The American Historical Review 117, no. 5 (2012): 1411-1430.

Andersson, J. "Controlling the American Future. RAND, the Commission for the Year 2000 and the Rise of futurology." In review (2014).

Aradau, C., and R. van Munster. Politics of Catastrophe. Genealogies of the Unknown. London: Routledge, 2011.

Aykut, S. "Comment gouverner un 'nouveau risque mondial?' La construction du changement climatique comme problème public à l'échelle globale, européenne, en France et en Allemagne." PhD diss., Paris: EHESS, Centre Koyre., 2012.

Beck, U. The Risk Society. London: Polity press, 1991.

Bell, D., and S. Graubard. The Year 2000. Work in Progress. Cambridge, MA: MIT Press, 1967.

Brown, N., ed. Contested Futures. A Sociology of Prospective Technoscience. Aldershot: Ashgate, 2000.

Callon, M., Y. Barthes, and P. Lascoumes. Acting in an Uncertain World. Cambridge, MA: MIT Press, 2011.

Dahan, Dalmedico A, ed. Les modeles du futur. Paris: La Decouverte, 2006.

Dahan Dalmedico, A. "Models and Simulations in Climate Change. Historical, Anthropological and Political Aspects." In Science without Laws, edited by Lunbeck Creager and Wise, 125-157. Durham, NC: Duke University Press, 2007.

van der Duin, P., C. A. Hazeu, P. Rademaker, and I. J. Schoonenboom, eds. Vijfentwintig jaar later. De toekomstverkenning van de WRR uit 1977 als leerproces [Twenty-five years later. The future study of the WRR in 1977 as a learning process]. Amsterdam: Amsterdam University Press, 2004.

Dutch National Archives. 2.03.02./12029 Archief Ministeries voor Algmeene Oorlogvoering van het Koninkrijk (AOK) en van AlgemeneZaken (AZ): Kabinet van de Minister-President (Archives of the Ministries for General Warfare of the Kindom and of General Affairs: Office of the prime minister). Inventory 12029; reports on the meetings of the committee.

Dutch National Archives. 2.03.02./12030 Archief Ministeries voor Algmeene Oorlogvoering van het Koninkrijk (AOK) en van AlgemeneZaken (AZ): Kabinet van de Minister-President (Archives of the Ministries for General Warfare of the Kindom and of General Affairs: Office of the prime minister). Inventory 12030: reports on the meetings of the committee.

Dutch National Archives. 2.03.07./7501 Archief van de Wetenschappelijke Raadvoor het Regeringsbeleid (Archives of the Scientific Council for Government Policy). Inventory 7501.

Dutch National Archives. 2.02.28/6968 Archive of the Dutch House of Representatives, 19451980, inventory nr. 6968.

Forrester, J. W. World Dynamics. Cambridge, MA: MIT Press, 1971. 
Fridjonsdottir, K. "Social Science and the Swedish Model." In Discourses on Society, edited by Wagner, Wittrock, and Whitley, 245-269. Amsterdam: Sociology of the Sciences Yearbook, Kluwer, 1991.

Ghamari Tabrizi, S. The Worlds of Herman Kahn. The Intuitive Science of Thermonuclear War. Cambridge, MA: Harvard University Press, 2005.

Haas, P. "Introduction: Epistemic Communities and International Policy Coordination." International Organization 46, no. 1 (1992): 1-35.

Halfman, W. "Measuring the Stakes: The Dutch Planning Bureaus." In Scientific Advice to Policy Making, edited by J. Lentsch and P. Weingart, 41-66. Opladen \& Farmington Hills, MI: Barbara Budrich, 2009.

Heclo, H. Policy and Politics in Sweden. Principled Pragmatism. Philadelphia: Temple University Press, 1987.

Heilbron, J, and M Lamont. Social knowledge in the Making. Chicago, IL: Chicago University Press, 2011.

Hoed, P. "A Variety of Counselors: One Hundred Years Permanent Advisory Bodies." [Eenkeur van raadgevers: honderd jaar vaste adviescolleges] In Just a Stone's Throw Away. On the Bridge between Science and Politics [Op steenworpafstand. Op de brug tussen wetenschap en politiek], edited by P. Den Hoed and A. G. Keizer, 13-236. Amsterdam: Amsterdam University Press, 2007.

den Hoed, P., and A. G. Keizer. "The Scientific Council for Government Policy: Between Science, Policy and More." In Scientific Advice to Policy Making, edited by J. Lentsch and P. Weingart, 67-82. Opladen \& Farmington Hills, MI: Barbara Budrich, 2009.

Hounshell, D. "The Cold War, RAND, and the Generation of Knowledge, 1946-1962." Historical Studies in the Physical and Biological Sciences 27, no. 2 (1997): 237-267.

Hughes, A., and T. Hughes, eds. Systems, Experts and Computers. The Systems Approach in Management and Engineering, World War II and After. Cambridge, MA: MIT Press, 2000.

Ingelstam, L. Methods of Advanced Planning. Stockholm: Royal College of Technology Planning group, 1967.

Ingelstam, L. "Socialdemokraterna och framtidsforskningen." Working Group for Futures Studies, Alva Myrdal's Archives, Swedish Labour Movement's Archives, Stockholm 5 (1971): 66.

Ingelstam, L. Solar vs Nuclear. Choosing Energy Future. Stockholm: Swedish Secretariat for Futures Studies, 1978.

Ingelstam, L., and K. Nibleus. "Socialistiska framtidsstudier." Aftonbladet, January 15, 1968.

IVA, Swedish Royal Academy of Engineers (Ingenjorsvetenskapsakademin). Forslag till ett institut for framtidsstudier. Stockholm: IVA, 1967.

Jantsch, E. Long Range Forecasting. Paris: OECD, 1967.

Jantsch, E. Perspectives on Planning. Paris: OECD, 1969.

Jasanoff, S. Designs on Nature. Princeton, NJ: Princeton University Press, 2005.

Jasanoff, Sheila, and Sang-Hyun Kim. "Sociotechnical Imaginaries and National Energy Policies." Science as Culture 22, no. 2 (2013): 189-196.

Kahn, H. On Thermonuclear War. Princeton, NJ: Princeton University Press, 1960.

Kahn, H., and A. Wiener. The Year 2000. New York: Hudson Institute, 1967.

Kalk, E. "We are no technocrats." [Wijzijngeentechnocraten] Katernen 2000 nr. 2 (1971).

Keizer, A. G. "Balance Artists between Policy and Science." [Evenwichtskunstenaarstussenbeleid en wetenschap] In Op steenworp afstand. Op de brug tussen wetenschap en politiek [Just a stone's throw away. On the bridge between science and politics], edited by P. Den Hoed and A. G. Keizer, 237-315. Amsterdam: Amsterdam University Press, 2007.

Lakoff, A. "Preparing for the Next Emergency." Public Culture 19, no. 2 (2007): 247-271.

Lamont, M., C. Camic, and N. Cross, eds. Social Knowledge in the Making. Chicago, IL: Chicago University Press, 2012.

van de Linde, E. J. G. "A Brief History of the Postwar Practice of Future Studies in the Netherlands." (Een korte geschiedenis van de naoorlogse praktijk van toekomstverkenning in Nederland) In Uitzicht. Toekomstverkennen met beleid [Out of sight: Exploring futures for policy making], edited by M. B. A. van Asselt, A. Faas, F. van der Molen, and S. A. Veenman, 155-184. Amsterdam: Amsterdam University Press, 2010.

Mallard, G., and A. Lakoff. "How Claims to Know the Future Are Used to Understand the Present. Techniques of Prospection in the Field of National Security." In Social Knowledge in 
the Making, edited by M. Lamont, C. Camic, and N. Cross, 339-379. Chicago, IL: Chicago University Press, 2011.

Marcuse, H. One Dimensional Man. New York: Beacon Press, 1964.

Meadows, D. H., D. L. Meadows, J. Randers, and W. W. Behrens III. The Limits to Growth. A report on the Club of Rome's Project on the Predicament of Mankind. New York: Beacon Books, 1972.

Mesarovic, M., and E. Pestel. De mensheid op een kruispunt. Amsterdam, 1974 (Club of Rome: Mankind at the Turning Point. The Second Report to the Club of Rome, 1974).

Myrdal, G. Planering som vardeproblem. Stockholm: Tiden, 1969.

Oden, B. Planering, värdestruktur och participation. Rapport till Arbetsgruppen för framtidsstudier. Ds. Ju 1972: 27. Stockholm.

OECD. The Social Sciences and the Policies of Governments. Advisory Group on the Social Sciences. Paris: OECD, 1966.

OECD. Science, Growth and Society. A New Perspective. The Brooks Report. OECD: Paris, 1971.

Polak, F. Het Zuknft ist verleden tijd. Elsevier: Amsterdam, 1955.

Schmelzer, M. "Born in the Corridors of the OECD. The Forgotten Origins of the Club of Rome." (2014). Unpublished, used with the permission of the author.

Smith, B. The RAND Corporation. Cambridge MA 1966.

Sommer, V. "From Futurology to Prognostika. Czechoslovak Futures Studies from 1968 to 1989." In Forging the future. Transnational perspectives on the history of prediction, edited by J. Andersson and E. Rindzeviciute. New York, NY: Routledge, Forthcoming.

Statsrådsberedningen, pressmeddelande (Council of Ministers Memo to the Press). February 1, 1971, and May 4, 1971, 2012.

Stenlas, N. ed. Science for Welfare and Warfare. Technology and State Initiative in Cold War Sweden. Sagamore Beach: Science history publications, Watson publishing, 2011.

Swedish Secretariat for Futures Studies. Futures Studies in Sweden. Stockholm: Swedish secretariat for futures studies, 1974.

Swedish Secretariat for Futures Studies. En presentation. Stockholm: Swedish secretariat for futures studies, 1975.

Swedish Secretariat for Futures Studies. Memos 19730822, $19730926,19740820$.

Tetlock, P. Expert Political Judgement. Princeton University Press, 2006.

Tiberg, J. "Framtidsstudier - vad hände sen?" Polhem 13, (1995).

Tweede Kamer. Rapport van de Commissie voorbereiding onderzoek toekomstige maatschappijstructuur [Report of the committee investigating future structure of society], 1970.

Van der Helm, R. "The Future According to Frederik Lodewijk Polak: Finding the Roots of Contemporary Futures Studies." Futures 37 (2005): 505-519.

Van Steenbergen, B.. "Critical Futures Research and Establishment Futurology." Proceedings of the International Congress in Futures Research, 17-21. Kyoto: Futurology Society of Japan, 1970.

Van Steenbergen, B.. De Wolff en de Wetenschappen': Katernen 2000, 2, Amersfoort, 1971.

Vieille Blanchard, E. "Les limites a la croissance dans un monde global." Doctoral diss., Centre Alexandre Koyre, Paris, 2011.

Wagner, P., B. Wittrock, and R. Whitley, eds. Discourses on Society. The Shaping of the Social Science Disciplines. Amsterdam: Sociology of the Sciences Yearbook, Kluwer, 1991.

Wittrock, B. Möjligheter och gränser. Framtidsstudier i politik och planering. Stockholm: Tiden, 1980.

Working Group for Futures Studies (Arbetsgruppen for framtidsstudier). Swedish national archives. Stockholm.

Working Group for Futures Studies (Arbetsgruppen for framtidsstudier). Alva Myrdal's Archives, Labour movements' archives. Stockholm.

WRR. De komendevijfentwintigjaar: eentoekomstverkenningvoor Nederland (The next twenty-five years: A survey of future developments in the Netherlands (report 15). Den Haag: WRR, 1977.

WRR. Exploring Futures for Policymaking. Synthesis of 'out of sight: Exploring Futures for Policymaking'. The Hague: WRR/Scientific Council for Government Policy, 2010.

Commissariat au Plan, Plan et prospective. Paris: 1972.

Interview with Bart van Steenbergen, August 31, 2010.

Interview with Lars Ingelstam, June 14, 2010.

Young, M, and Social Science Research Council. Forecasting and the Social Sciences. London: Heinemann Educational Books, 1968. 